ISSN 1392-3196 / e-ISSN 2335-8947

Zemdirbyste-Agriculture, vol. 108, No. 4 (2021), p. 291-296

DOI 10.13080/z-a.2021.108.037

\title{
The presence of pathogenic bacteria Pseudomonas syringae in cereals in Lithuania
}

\author{
Jurgita KELPŠIENÉ ${ }^{1}$, Donatas ŠNEIDERIS ${ }^{2}$, Daiva BUROKIENE ${ }^{2}$, \\ Skaidrẻ SUPRONIENE ${ }^{1}$ \\ ${ }^{1}$ Lithuanian Research Centre for Agriculture and Forestry \\ Instituto 1, Akademija, Kèdainiai distr., Lithuania \\ E-mail: jurgita.kelpsiene@lammc.lt \\ ${ }^{2}$ Nature Research Centre \\ Akademijos 2, Vilnius, Lithuania
}

\begin{abstract}
Pseudomonas syringae pathovars cause bacterial diseases of cereals in nearly all temperate and subtropical cerealgrowing regions. As being of low importance compared to fungal diseases, $P$. syringae has not been studied in cereal crops in Lithuania. However, leaf blights and glume discolorations, uncharacteristic of fungal diseases, were found relatively frequently in the fields. Therefore, the study aimed to identify the occurrence of $P$. syringae in cereals grown in Lithuania.

In this study, cereal crops were tested for the presence of plant pathogen $P$. syringae. In total, 452 symptomatic plant samples of winter wheat, winter triticale, spring wheat and spring barley were collected in 2013-2015. Symptoms of leaf blight and basal glume blotch on grain were more frequently detected in spring and winter wheat crops than in winter triticale and spring barley. Symptomatic leaves and grain yielded 113 P. syringae strains (51 from leaves and 62 from grain), but only 13 strains (10 from wheat, 2 from triticale and 1 from barley) were pathogenic to host plants when tested by spray method (SM). These strains were isolated from grain (10 strains) and leaves (3 strains) of all sampled plant species originating from different districts of the country. Based on 16S rRNA gene sequence analysis, leaf injection method (LIM) and origin of pathogenic strain, it can be assumed that $P$. syringae pv. atrofaciens is the dominat causal agent of bacterial diseases of cereals, particularly basal glume blotch of wheat.
\end{abstract}

Key words: wheat, pathogenic bacteria, basal glume blotch, leaf blight.

\section{Introduction}

Cereal plants play an essential role in the agriculture of Lithuania and worldwide. Plant pathogenic bacteria may reduce grain yield, especially when environmental conditions are favourable for epidemic development, and host plants are susceptible to the pathogen.

Pseudomonas syringae van Hall 1902 is a heterogeneous widespread bacterial phytopathogen, subdivided into more than 60 pathovars based on the pathogenic characteristics, 9 genomospecies defined by DNA-DNA hybridisation and 13 phylogenetic groups defined by multilocus sequence analysis (Baltrus et al., 2017). Leaf blight and basal glume blotch of cereals are caused by $P$. syringae pv. syringae and $P$. syringae pv. atrofaciens (Matveeva et al., 2008; Kazempour et al., 2010; Valencia-Botín, Cisneros-López, 2012; Glinushkin et al., 2016). P. syringae pv. syringae can infect an extensive host range of monocotyledonous and dicotyledonous plants (Iličic et al., 2016; Choi et al., 2017). P. syringae pv. atrofaciens mainly infects the monocotyledonous plants and is considered as one of the primary bacterial pathogens of cereals in Europe (Pasichnyk, Butsenko, 2018); however, it can also cause leaf spots of dicotyledonous weeds such as Sonchus arvensis and Papaver argemone (Butsenko et al., 2021).

Leaf symptoms incited by $P$. syringae pv. syringae appear at booting to early heading. Numerous tiny, water-soaked spots are formed on the flag leaf and the two leaves below this leaf. Within two to three days, spots expand and often coalesce into large, greyishgreen and desiccated areas, which within a week become necrotic and bleach to a light tan or white (Valencia-Botín, Cisneros-López, 2012). Leaves affected by P. syringae pv. atrofaciens show small, dark and water-soaked spots, which tend to enlarge and turn yellow and finally brown, when they become necrotic. Wheat glumes affected by P. syringae pv. atrofaciens have a dull, brownish-black area (blotches or streaks) at the base of each glume covering the kernel. Blotches appear near the base of glumes, while streaks may extend more than halfway

Please use the following format when citing the article:

Kelpšienė J., Šneideris D., Burokienè D., Supronienė S. 2021. The presence of pathogenic bacteria Pseudomonas syringae in cereals in Lithuania. Zemdirbyste-Agriculture, 108 (4): 291-296. DOI 10.13080/z-a.2021.108.037 
up glumes (Kazempour et al., 2010). Diseased seeds at the basal end have dark brown lesions and are the most important pathogen reservoir. Symptoms may also occur on the upper part of the stem, significantly just above the nodes (Duveiller et al., 1997).

Diagnosis of bacterial diseases based on expressed symptoms is difficult, because they can be confused with those caused by some fungi or other biotic and abiotic factors (Morris et al., 2013; Xin et al., 2018). Therefore, it is likely that these diseases could be more widespread and important than is commonly thought. In general, compared to the other plant pathogenic bacteria, $P$. syringae pathovars are noted as the most common and well-studied ones (Tripathi, 2017; Xin et al., 2018). However, those causing leaf blight and basal glume blotch of wheat and other cereal pathogens are limited, and only scarce information is available, especially on yield losses and disease epidemiology (Valencia-Botín, Cisneros-López, 2012; Butsenko et al., 2021). P. syringae pv. atrofaciens has been more extensively studied since the eighties of the $20^{\text {th }}$ century in Europe and was noted as important pathogen of wheat basal glume blotch in Russia, Ukraine, Bulgaria, Italy, Germany, New Zealand and Iran (Matveeva et al., 2008; Kazempour et al., 2010; Butsenko et al., 2021). In Germany, this pathogen has been regularly isolated since 1986, and epiphytic strains of $P$. syringae pv. atrofaciens were frequently detected on seeds and plants of wheat and barley (Kietzel, Rudopph, 1997). Epiphytic populations are the primary inoculum for plant infection and can cause significant plant damage in favourable weather conditions (Xin et al., 2018; Butsenko et al., 2021). At such conditions, yield losses may reach up to $50 \%$ (Valencia-Botín, CisnerosLópez, 2012).

In Lithuania and other Baltic countries, fungal diseases of cereals received much attention, and the studies on bacterial diseases caused by $P$. syringae covered only some leguminous plants, stone fruits and nuts (Vasinauskiene, 1997; Vasinauskienè et al., 2008; Konavko et al., 2014). As a cereal pathogen, P. syringae has not been studied not only in Lithuania but also in neighbouring countries. Supposedly bacterial diseases in cereals have not been investigated thoroughly, because they occur sporadically and only under extremely humid conditions in spring or summer (Glinushkin et al., 2016; Xin et al., 2018). Recently, the atypical for fungal injuries, leaf blights and glume discolorations have been frequently detected on Lithuania-grown cereal plants suggesting the $P$. syringae infections.

Therefore, this study was aimed to isolate the causal agents from symptomatic plants, identify the presence of $P$. syringae on cereals and test its pathogenicity.

\section{Materials and methods}

The experiment was carried out during 20132020 at the Laboratory of Microbiology, Institute of Agriculture, Lithuanian Research Centre for Agriculture and Forestry, and Nature Research Centre.

Sample collection and isolation of bacteria. Symptomatic leaves and seeds of winter and spring wheat (Triticum aestivum L.), winter triticale $(\times$ Triticosecale Wittm. ex A. Camus) and spring barley (Hordeum vulgare L.) were collected from various regions of Lithuania in 2013-2015. The samples of leaves were collected during the cereal growing season $(\mathrm{BBCH} 13$ $77)$ and those of seeds after harvest (BBCH 89). Seeds and segments (approximately $1.0 \mathrm{~cm}$ in length) of leaves were dipped in a $1 \% \mathrm{NaClO}$ (sodium hypochlorite) solution for 3 minutes, rinsed three times in sterile distilled water and placed to dry for $1 \mathrm{~h}$ on sterile filter paper in a laminar. Then the seeds or leaves were placed on a modified King's B (KBC) medium, supplemented with $75 \mathrm{mg}$ of cycloheximide, $75 \mathrm{mg}$ of penicillin and $45 \mathrm{mg}$ novobiocin (Schaad et al., 2001) and incubated at $26-27^{\circ} \mathrm{C}$ temperature for $1-2$ days. Bacteria were purified on KBC medium, and those producing bluegreen fluorescent pigment under UV light $(312 \mathrm{~nm})$ were subjected to physiological tests.

Physiological tests. Purified fluorescent bacteria were analysed for LOPAT tests: levan production from sucrose, oxidase reaction, pectolytic activity on potato, the presence of arginine dihydrolase activity and hypersensitivity to tobacco leaves (Schaad et al., 2001). After the performance of LOPAT tests, strains positive for levan production and tobacco leaves hypersensitivity but negative for oxidase reaction, pectolytic activity on potato and arginine dihydrolase activity were considered as Pseudomonas syringae and were subjected to the pathogenicity tests performed on host plants.

Pathogenicity tests. For the evaluation of the $P$. syringae strain pathogenicity to host plants, three different methods (SM, LIM and DLA) were performed.

Spray method (SM). The test was carried out in controlled growth chamber Climacell 707 (MMM Medcenter Einrichtungen GmbH, Germany) conditions. Spring wheat (Triticum aestivum L.) cultivar 'Hamlet', spring barley (Hordeum vulgare L.) cultivar 'Luokè', winter wheat (Triticum aestivum L.) cultivar 'Širvinta 1', and winter triticale $(\times$ Triticosecale Wittm. ex A. Camus) cultivar 'Borowik' were grown at $20 \pm 0.5^{\circ} \mathrm{C}$ temperature, $16 \mathrm{~h}$ day light period, $70-80 \%$ humidity and were watered according to the need (approximately twice per week). Five plants per pot (90 mm wide and $110 \mathrm{~mm}$ high) were grown in compost produced by UAB 'Agrochema' $(\mathrm{pH}$ 5.5-7.0, N 50-150 $\mathrm{mg} \mathrm{L}^{-1}, \mathrm{~K}^{2} \mathrm{O} 100-200 \mathrm{mg} \mathrm{L}^{-1}, \mathrm{P}^{-}$ $\left.30-70 \mathrm{mg} \mathrm{L}^{-1}, \mathrm{MgO} 20-50 \mathrm{mg} \mathrm{L}^{-1}\right)$. When plants reached $\mathrm{BBCH} 12-13$ growth stage, they were spray inoculated $\left(\sim 1 \mathrm{ml}\right.$ per plant) with bacterial suspension $\left(10^{7}\right.$ cells $\left.\mathrm{ml}^{-1}\right)$. Host plant seedlings were inoculated with 13 strains of selected $P$. syringae and two reference bacteria: P. syringae pv. syringae (PSS), strain No. CFBP 4108, Van Hall 1902, collection No. ICMP 6386, geographic origin Japan, host plant Hordeum vulgare, and $P$. syringae pv. atrofaciens (PSA), strain No. CFBP 3587, Mac Culloch 1920, Young, Dye \& Wilkie 1978, collection No. IMV 2399, geographic origin Ukraine, Kiev, host plant Triticum durum L. For negative control, seedlings were inoculated with sterile distilled water (SDW). Pots were randomized with four replications of each treatment. Inoculated plants were covered with plastic bags for the initial $72 \mathrm{~h}$ to keep plant surfaces wet and incubated at the above mentioned chamber conditions. After incubation (3-7 days), strains causing small, water-soaked, greyish-green lesions on seedlings' leaves were considered pathogenic to host plants. When disease symptoms appeared, re-isolations of pathogenic bacteria were performed: to ensure the presence of $P$. syringae, parts of the symptomatic tissues were plated on KBC medium and incubated for $48 \mathrm{~h}$ at $25^{\circ} \mathrm{C}$ temperature. The severity of leaf blight was assessed according to the scale from $1 \%$ to $75 \%$ proposed by Duveiller et al. (1997). Experiment was repeated three times.

Leaf injection method (LIM). Seedlings of host plants (spring wheat, spring barley, winter triticale and winter wheat) were grown on wet filter paper in the Petri dishes $(90 \times 20 \mathrm{~mm})$ at room temperature $\left(21 \pm 2^{\circ} \mathrm{C}\right)$ until they reached $2-4 \mathrm{~cm}$ in length (BBCH 09). The upper part of the leaves was inoculated by inserting a sterile needle filled with fresh bacterial cell suspension $\left(10^{7}\right.$ cells $\left.\mathrm{ml}^{-1}\right)$. P. syringae strains were tested on four seedlings, 
and the test was repeated three times. Reference bacteria P. syringae pv. syringae and P. syringae pv. atrofaciens and SDW were also included in the test. Leaves were examined after 2-4 days, strains causing necrotic lesions surrounded by chlorotic area were considered pathogenic to the host plant.

Detached leaf assay (DLA). For this test, seedling leaves $(\mathrm{BBCH} 13-14)$ were sampled from the fields, and surface was sterilized in a $3 \% \mathrm{NaClO}$ solution for 3 minutes. Five-cm long leaves were cut off, and the centre of the top of each leaf was wounded using a sterile pipet tip. Then leaf segments were placed in 100 $\mathrm{mm}$ Petri dishes (four leaves per plate) on the surface of $0.5 \%$ water agar containing $10 \mathrm{mg} \mathrm{L}^{-1}$ kinetin as senescence retardant and inoculated with a $5 \mu \mathrm{l}$ droplet of bacterial suspension $\left(10^{7} \mathrm{CFU} \mathrm{m \textrm {m } ^ { - 1 }}\right)$ containing $0.08 \%$ of Tween 20 (G-Biosciences, USA). Control leaves were inoculated with SDW containing Tween 20. For this test, reference strains of both pathovars were also used. Petri dishes were kept at room temperature $\left(21 \pm 2^{\circ} \mathrm{C}\right)$ for 5 days. Lesion size in $\mathrm{mm}$, based on its average length and width, was measured daily.

DNA extraction. For the DNA extraction, bacteria were grown on $\mathrm{KBC}$ medium at $27^{\circ} \mathrm{C}$ temperature for 1 day. DNA extraction was performed using ZR Fungal/Bacteria DNA MiniPrep (Zymo Research, USA) according to the manufacturer's instructions. DNA concentration was measured using Biophotometer (Eppendorf, Germany).

Polymerase chain reaction (PCR). Bacterial ribosomal RNA gene was amplified by PCR using universal bacterial primers $8 \mathrm{~F}$ (5'-AGA GTT TGA TCC TGG CTC AG-3') and 1492R (5'-GTT ACC TTG TTA CGA CTT-3') (Barghouthi, 2011). PCR reaction was performed in a $50 \mu \mathrm{l}$ of the reaction mixture containing $5 \mu \mathrm{l}$ of $10 \times$ PGR reaction buffer (included in polymerase kit) and $1 \mu \mathrm{l}$ of dNTP Mix, $10 \mathrm{mM}$ each (Thermo Fisher Scientific Baltics, Lithuania), $1 \mu \mathrm{l}$ of

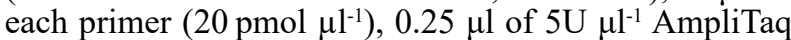
Gold polymerase (Applied Biosystems, USA), $1 \mu \mathrm{l}$ of sample DNR (100 ng $\left.\mu^{-1}\right)$ and $40.75 \mu$ of nuclease-free water. PCR amplification was performed in a Veriti 96Well Thermal Cycler (Applied Biosystems) using the following conditions: $95^{\circ} \mathrm{C}$ for $10 \mathrm{~min}, 40$ cycles $\left(95^{\circ} \mathrm{C}\right.$ for $1 \mathrm{~min}, 54^{\circ} \mathrm{C}$ for $1 \mathrm{~min}, 72^{\circ} \mathrm{C}$ for $1 \mathrm{~min}$ ) and $72^{\circ} \mathrm{C}$ for $10 \mathrm{~min}$.

Electrophoresis. PCR products were visualized under UV-light in $1 \%$ agarose gel using GeneRuler $100 \mathrm{bp}$ plus DNA Ladder (Thermo Fisher Scientific Baltics) as a marker.

PCR product excision from gel. PCR products were cut out from agarose gel and purified using GeneJET Gel Extraction Kit (Thermo Fisher Scientific Baltics) according to the manufacturer's protocol.

Nucleotide sequence analysis. PCR products were sequenced at BaseClear (The Netherlands). Identified nucleotide sequences were processed and analysed using the program package DNASTAR and the database NCBI BLAST.

Statistical analysis. All experiments were repeated three times. The experimental data were processed by the analysis of variance (ANOVA). The least significant difference (LSD) was calculated using the ANOVA.

\section{Results}

Isolation of bacteria. A total of 452 grain (273) and leaf (179) samples showing symptoms of bacterial leaf blight and grain infection were collected during 2013-2015 (Table 1).

Table 1. Sampling information

\begin{tabular}{|c|c|c|c|c|c|}
\hline $\begin{array}{l}\text { Coding } \\
\text { of strains }\end{array}$ & $\begin{array}{l}\text { Host } \\
\text { plant }\end{array}$ & $\begin{array}{c}\text { Plant } \\
\text { part }\end{array}$ & $\begin{array}{c}\text { Number of } \\
\text { samples }\end{array}$ & $\begin{array}{c}\text { Number of } \\
\text { bacteria isolations }\end{array}$ & $\begin{array}{c}\text { Fluorescent bacteria } \\
\text { on KBC medium }\end{array}$ \\
\hline SWG & spring wheat & grain & 142 & 129 & 119 \\
\hline SWL & spring wheat & leaves & 88 & 95 & 61 \\
\hline WWG & winter wheat & grain & 110 & 117 & 74 \\
\hline WWL & winter wheat & leaves & 74 & 118 & 102 \\
\hline TG & winter triticale & grain & 12 & 25 & 17 \\
\hline TL & winter triticale & leaves & 11 & 33 & 14 \\
\hline $\mathrm{BG}$ & spring barley & grain & 9 & 10 & 6 \\
\hline \multirow[t]{2}{*}{$\mathrm{BL}$} & spring barley & leaves & 6 & 15 & 11 \\
\hline & & Total & 452 & 542 & 387 \\
\hline
\end{tabular}

Bacteria isolated from necrotic leaf segments and seeds (whose base end was dark brown) on KBC medium yielded 542 bacterial isolates. The fluorescent blue-green pigment on this medium was produced by 387 whitish, translucent bacterial colonies after $48 \mathrm{~h}$ of incubation. During the performance of LOPAT tests, 113 strains (51 isolated from leaves and 62 from grain) gave positive reaction for levan production but negative for oxidase reaction and arginine dihydrolase activity and did not cause the soft rot on potato tubers; however, 45 of these strains induced a clear hypersensitive reaction to tobacco leaves, and the rest (69) did not (Table 2).

Using the spray method (SM), all 113 strains were evaluated for their pathogenicity to host plants, and only 13 strains ( 10 from grain and 3 from leaves) showed the positive reaction and, therefore, were selected for further studies. These strains were isolated from grain and leaves of all sampled plant species and originated from different districts of Lithuania (Table 3).

Pathogenicity tests. Leaf blight symptoms on host plant seedlings sprayed with the test bacteria mainly were very weak (disease severity $0.1-0.5 \%$ )
(Table 3). No symptoms on host plants were observed with SDW. Leaf blight severity caused by $P$. syringae pv. atrofaciens $(7.5 \%)$ was higher than by $P$. syringae $\mathrm{pv}$. syringae $(3.5 \%)$. Leaf injection method (LIM) showed that 4 strains isolated from winter wheat grain (WWG74, WWG10, WWG2 and WWG11), 1 from winter wheat leaves (WWL4), 2 from spring wheat grain (SWG32, SWG11) and 1 from winter triticale leaf (TL1) as well as $P$. syringae pv. atrofaciens were able to cause the typical for $P$. syringae pv. atrofaciens dark margins around the inoculation points (Toben et al., 1989). Other strains from spring wheat grain (SWG41 and SWG53), spring wheat leaf (SWL6), winter triticale grain (TG1) and spring barley grain (BG8) were tested, and like SDW did not cause any discoloration. P. syringae pv. syringae induced water-soaked spots on leaves, which became necrotic and turned from grey-green to tan-white (Figure 1). The entire leaves later became necrotic. P. syringae pv. atrofaciens induced small dark green to brown, watersoaked irregular lesions, 2-5 mm in length (Figure 2). These elongated up to $5 \mathrm{~mm}$ lessions became yellow and then brown, when the tissue finally dried. 
Table 2. Pseudomonas syringae strain reaction to the LOPAT tests and pathogenicity to host plants (spay method)

\begin{tabular}{|c|c|c|c|c|c|c|c|c|}
\hline $\begin{array}{c}\text { Preliminary } \\
\text { species name }\end{array}$ & $\mathrm{L}$ & $\mathrm{O}$ & $\mathrm{P}$ & A & $\mathrm{T}$ & HP & $\begin{array}{l}\text { Coding } \\
\text { of strains }\end{array}$ & $\begin{array}{l}\text { Total No. } \\
\text { of isolates }\end{array}$ \\
\hline P. syringae & + & - & - & - & + & + & $\begin{array}{l}\text { SWG32, SWG41, SWG53, WWG74, TG1, BG8, SWL6, } \\
\text { SWG11, WWL4, WWG2, TL1, WWG10, WWG11 }\end{array}$ & 13 \\
\hline P. syringae & + & - & - & - & + & - & $\begin{array}{l}\text { SWG70, SWG72, SWG84, SWG89, SWL21, SWL17, } \\
\text { SWL27, SWL38, SWL47, SWL53, SWL57, SWL64, } \\
\text { SWL2, SWL11, SWL19, SWL39, SWL62, WWL1, WWL8, } \\
\text { WWL18, WWL19, WWL20, WWL26, WWL33, WWL35, } \\
\text { WWL42, TL2, TL13, TL21, TL27, TL32, TL33 }\end{array}$ & 32 \\
\hline P. syringae & + & - & - & - & \pm & \pm & $\begin{array}{l}\text { SWG58, SWG59, SWG60, SWG61, SWG62, SWG64, } \\
\text { SWG94, SWL1, SWG81, SWG91, SWG97, SWG98, TG3, } \\
\text { TG5, TG14, TG17, TG23 }\end{array}$ & 17 \\
\hline P. syringae & + & - & - & - & \pm & - & $\begin{array}{l}\text { SWG7, SWG25, SWG28, SWG47, SWG48, SWG55, } \\
\text { SWG82, SWG83, SWG79, SWG87, SWG90, SWG92, } \\
\text { SWG96, SWG99, SWL3, SWL29, SWL30, SWL36, } \\
\text { WWG37, WWG45, WWG54, WWG61, WWG70, } \\
\text { WWG21, WWG29, WWG46, WWG71, WWG86, } \\
\text { WWG98, WWG99, WG110, WWL2, WWL5, WWL14, } \\
\text { WWL25, WWL29, WWL34, WWL36, WWL37, WWL40, } \\
\text { WWL50, WWL57, WWL59, TG2, TG18, TG19, TG20, } \\
\text { TG24, TG25, TL4, TL14, TL30 }\end{array}$ & 51 \\
\hline
\end{tabular}

$\mathrm{L}$ - levan production, $\mathrm{O}$ - oxidase reaction, $\mathrm{P}$ - pectolytic activity on potato, $\mathrm{A}$ - arginine dihydrolase activity, $\mathrm{T}$ - tobacco leaves hypersensitivity, HP - host plant sensitivity

Table 3. Pathogenicity of strains of Pseudomonas syringae to cereals using seedling spray (SM), leaf injection (LIM) and detached leaf assay (DLA) methods (2013-2020)

\begin{tabular}{|c|c|c|c|c|c|c|}
\hline Strain & $\begin{array}{l}\text { Host } \\
\text { plant }\end{array}$ & $\begin{array}{c}\text { Plant } \\
\text { part }\end{array}$ & $\begin{array}{c}\text { Area } \\
\text { of origin }\end{array}$ & $\begin{array}{c}\text { SM: } \\
\text { SLB HP \% }\end{array}$ & $\begin{array}{l}\text { LIM: } \\
\text { HP }\end{array}$ & $\begin{array}{c}\text { DLA: } \\
\text { WW lesion size } \mathrm{mm}\end{array}$ \\
\hline SWG11 & spring wheat & grain & Pakruojis & $0.2 \mathrm{a}$ & + & 4.9 bcdef \\
\hline SWG32 & spring wheat & grain & Kèdainiai & $0.3 \mathrm{a}$ & + & $4.6 \mathrm{ab}$ \\
\hline SWG41 & spring wheat & grain & Jurbarkas & $0.3 \mathrm{a}$ & - & $4.5 \mathrm{a}$ \\
\hline SWG53 & spring wheat & grain & Kretinga & $0.4 \mathrm{a}$ & - & $4.7 \mathrm{abc}$ \\
\hline SWL6 & spring wheat & leaves & Kaunas & $0.5 \mathrm{a}$ & - & 4.9 cdef \\
\hline WWG2 & winter wheat & grain & Pasvalys & $0.1 \mathrm{a}$ & + & 4.8 bcdef \\
\hline WWG10 & winter wheat & grain & Kaunas & $0.3 \mathrm{a}$ & + & 4.8 bcdef \\
\hline WWG11 & winter wheat & grain & Kèdainiai & $0.1 \mathrm{a}$ & + & $4.6 \mathrm{abc}$ \\
\hline WWG74 & winter wheat & grain & Biržai & $0.3 \mathrm{a}$ & + & $5.0 \mathrm{def}$ \\
\hline WWL4 & winter wheat & leaves & Kaunas & $0.1 \mathrm{a}$ & + & 4.8 bcdef \\
\hline TG1 & winter triticale & grain & Telšiai & $0.3 \mathrm{a}$ & - & 4.9 cdef \\
\hline TL1 & winter triticale & leaves & Kaunas & $0.1 \mathrm{a}$ & + & 4.9 bcdef \\
\hline BG8 & spring barley & grain & Ukmergè & $0.4 \mathrm{a}$ & - & 4.8 abcd \\
\hline PSA & T. durum & grant - & Ukraine & $7.5 \mathrm{c}$ & + & $5.1 \mathrm{f}$ \\
\hline PSS & H. vulgare & - & Japan & $3.5 \mathrm{~b}$ & + & 5.1 def \\
\hline
\end{tabular}

Note. PSA - reference bacteria of $P$. syringae pv. atrofaciens, PSS - reference bacteria of $P$. syringae pv. syringae; SLB HP-severity of leaf blight on the host plant (HP); WW - winter wheat; means followed by the same letters are not significantly different.

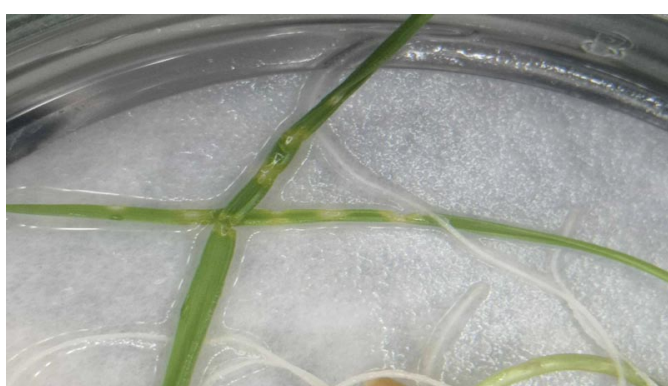

Figure 1. Symptoms using leaf spray method (SM) of Pseudomonas syringae pv. syringae

Using detached leaf assay (DLA), disease symptoms on host plant leaf were clearly expressed in all tested bacterial strains. Symptoms on a leaf at the point of inoculation initially appeared as a small water drop. After two days, the water-soaked spots subsequently became oval-shaped necrotic lesions surrounded by yellow chlorotic areas. Leaf segments inoculated with SDW displayed no visible lesions. Inoculation with bacterial strains produced $4.5-5.1 \mathrm{~mm}$ size lesions on the leaf (Table 3).

Nucleotide sequence analysis. For 16S rRNA gene sequence, $P$. syringae 6 strains: SWG11,

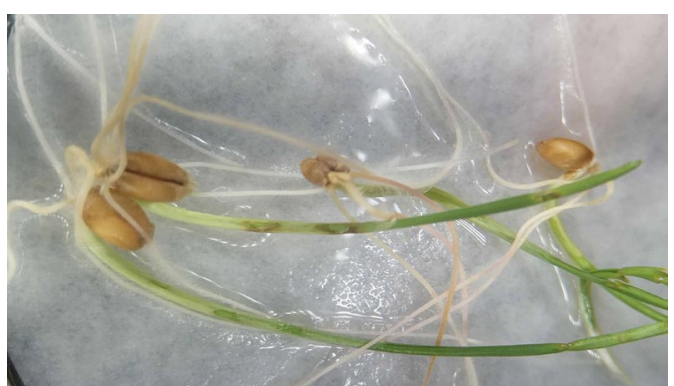

Figure 2. Symptoms using leaf spray method (SM) of Pseudomonas syringae pv. atrofaciens

SWG32, WWG11, WWG2, WWG74 and TL1 that were pathogenic to host plants during all three (SM, LIM and DLA) methods, were selected. Amplification of the 16S rRNA gene resulted in 1411 bp length fragments. Based on nucleotide sequence analysis, all selected strains exhibited greater than $99.8 \%$ (pairwise nucleotide identity) similarity to $P$. syringae pv. atrofaciens strain No. LMG 5095, host plant Triticum aestivum (GenBank ID CP028490). It is known that the 16S rRNA gene does not provide sufficient resolution to separate the closely related strains (pathovars) within the same species. Therefore, it just can be assumed that strains isolated 
from symptomatic cereal grain and leaves during 20132015 belong to $P$. syringae species.

\section{Discussion}

Researchers around the world (Sundin et al., 2016; Tripathi, 2017; Xin et al., 2018) have noticed an increasing risk of phytopathogenic bacteria for plant growth including cereals, especially wheat, one of the most valuable and important essential grain crops that ranks first in the world's sown area (Valencia-Botín, CisnerosLópez, 2012; Suszanowicz et al., 2019; Butsenko et al., 2021). Considering that bacterial diseases have not been studied in cereal crops of Lithuania and other Baltic countries before and that the atypical for fungal diseases leaf spots and glume discolorations are found rather frequently on cereals in the fields, this study was aimed to identify the occurrence of $P$. syringae in syptomatic leaves and grain of wheat, barley and triticale.

In the current study, symptoms of leaf bligh and basal glume blotch caused by $P$. syringae have been examined in Lithuania grown cereal crops for the first time. Symptoms of above mentioned diseases were more frequently detected in spring and winter wheat crops than in winter triticale and spring barley suggesting that the latter may be more resistant to $P$. syringae infections. The other reason is that the spread of bacterial diseases may be also influenced by the environmental conditions. It was shown previously that the symptoms of the basal glume blotch caused by $P$. syringae pv. atrofaciens varied depending on farming practices, the growth stage and the environmental factors (Patyka, 2016). Increased amounts of nitrogen, phosphate and potassium fertilisers increased the potential of wheat infection with this bacteria.

Symptomatic leaf and grain samples collected during the experiment yielded 113 strains ( 51 isolated from leaves and 62 from grain), which were identified based on the LOPAT tests as P. syringae. However, most of the strains $(88.5 \%)$ did not induce the disease symptoms on host plants when tested by spray method in the controlled conditions. It is known from previous studies (Kietzel, Rudopph, 1997; Valencia-Botín, Cisneros-López, 2012; Butsenko et al., 2021) that epiphytic $P$. syringae is present on the surfaces of wheat plants and other hosts. High humidity favours the abundance of epiphytic population of $P$. syringae, and the size of such population correlates quantitatively with the incidence of disease outbreaks (Xin et al., 2018). Pathogenic and epiphytic $P$. syringae have been identified in cereals in Lithuania for the first time. $P$. syringae pv. atrofaciens has been the primary causative agent of bacterial diseases of wheat, particularly basal glume rot of wheat, for many years in other countries (Matveeva et al., 2008; Kazempour et al., 2010; Butsenko et al., 2021).

However, spray method (SM) showed that the isolates of $P$. syringae were weak cereal pathogens on their own hosts. The SM and DLA methods showed that they have the capacity to cause disease. Using DLA, the isolates were almost as effective as a positive control of reference strains (Table 3). Both latter methods involved physical wounds on plants, while SM did not. In addition, hostpathogen interaction is complicated and multi-layered. Also, an important role might have the exact spraying time (morning or evening) and method. P. syringae is abundant in the environment and it participates in snow formation in the atmosphere, is present in rain, streams and other water sources (Morris et al., 2013). If it could invade plants freely, the devastation would be immeasurable. Instead, it is an opportunistic pathogen relying on other factors like fungal infections or feeding insects to make wounds in plants that help it infiltrate hosts. However, its share abundance ensures that $P$. syringae is always present and ready to take advantage of favourable conditions that might result in a spontaneous epidemic. According to Patyka (2016) and Butsenko et al. (2021), the disease did not cause a lot of losses, but there need to be favourable weather conditions for the disease to spread out. It can be stated that, if Lithuanian summers are warm and rainy, the disease will spread out quite fast.

Analysing the results of $16 \mathrm{~S}$ rRNAgene sequence analysis, it cannot be proved that the obtained strains belong to $P$. syringae pv. atrofaciens. However, based on the sequence data supported by typical for $P$. syringae pv. atrofaciens lesions caused on the leaf injection points and origin of pathogenic strain (most of strain obtained from symptomatic grain), it can be assumed that $P$. syringae pv. atrofaciens is the dominat causative agent of bacterial diseases of cereals, particularly basal glume blotch of wheat. This assumption is supported by the studies of other researches (Kazempour et al., 2010; Suszanowicz et al., 2019; Butsenko et al., 2021).

\section{Conclusions}

1. Research results showed that symptoms of bacterial blight on leaves and dark brown lesions at the basal end of grain were around 10 times more frequently detected in spring and winter wheat than in winter triticale and spring barley.

2. Symptomatic leaves and grain (total 452) yielded 113 Pseudomonas syringae strains (45\% from leaves and $55 \%$ from grain), most of which $(88.5 \%$ ) were non pathogenic to host plants when tested by spray method (SM) in the controlled growth chamber conditions.

3. Host pathogenic $P$. syringae strains (total 13) were isolated from grain (10 strains) and leaves (3 strains) of all sampled plant species (spring wheat, winter wheat, winter triticale and spring barley) originating from different parts of the country, confirming that diseases caused by P. syringae are present in Lithuania grown cereals.

4. Based on 16S rRNA gene sequence analysis, leaf injection method (LIM) and origin of pathogenic strain (most of the strains obtained from symptomatic grain), it can be assumed that $P$. syringae pv. atrofaciens is the dominating causative agent of bacterial diseases of cereals, particularly basal glume blotch of wheat.

\section{Acknowledgements}

This study was supported by the long-term research programme "Harmful Organisms in Agro and Forest Ecosystems" implemented by Lithuanian Research Centre for Agriculture and Forestry.

\section{References}

Baltrus D. A., McCann H. C., Guttman D. S. 2017. Evolution, genomics and epidemiology of Pseudomonas syringae. Molecular Plant Patholnog 18 (1)· 152-168.

https://doi.org/10.1111/mpp.12506

Barghouthi A. A. 2011. A universal method for the identification of bacteria based on general PCR primers. Indian Journal of Micrnhinlnoy $51(4) \cdot 430-444$ https://doi.org/10.1007/s12088-011-0122-5

Butsenko L., Pasichnyk L., Kolomilets Y., Kalinichenko A., Suszanowicz D., Sporek M., Patyka V. 2021. Characteristic of Pseudomonas syringae pv. atrofaciens isolated from weeds of wheat field. Annlied Sciences, 11 (1): 286. https://doi.org/10.3390/app11010286

Choi O., Kang B., Cho S. K. Park J., Lee Y., Kim W.-I., Marunga J., Hwang I., Kim J. 2017. Identification of Pseudomonas syringae pv. syringae causing bacterial leaf blight of Miscanthus sinensis. Journal of Plant Diseases and Protection 174: 97-100 https://doi.org/10.1007/s41348-016-0058-4 
Duveiller E., Fucikovsky L., Rudolph K. (eds). 1997. The Bacterial Diseases of Wheat: Concepts and Methods of Disease Management. CIMMYT, Mexico D.F., 78 p.

Glinushkin A. P., Beloshapkina O. O., Solovykh A. A., Sudarenkov G. V., Molnár J. 2016. Bacterial diseases of wheat in the Southern Ural: manifestations, biological characteristics and monitoring features. Acta Phytonathologica et Fntomologica Hungarica 51 (1): 57-67. https://doi.org/10.1556/038.51.2016.1.5

Iličic R., Balaž J., Stojšin V., Bagi F., Pivić R., StanojkovićSebić A., Jošić D. 2016. Molecular characterization of Pseudomonas syringae pvs. from different host plants by repetitive sequence-based PCR and multiplex-PCR. 7emdirhyste-Agriculture, 103 (2): 199-206. https://doi.org/10.13080/z-a.2016.103.026

Kazempour M. N., Kheyrgoo M., Pedramtar H., Rahimian H. 2010. Isolation and identification of bacterial glum blotch and leaf blight on wheat (Triticum aestivum L.) in Iran. A frican Inurnal of Rintechnolngy, 9 (00) 2860-2865. https://www.cabi.org/isc/abstract/20ّ1031798́07

Kietzel J. V., Rudopph K. 1997. Epiphytic occurrence of Pseudomonas syringae pv. atrofaciens. Pseudomonas syringae pathovars and related pathogens. Developments in Plant Pathology Series. Rudolph K. et al. (eds). Kluwel Academic Publishers, n. 29-34. https://doi.org/10.1007/978-94-011-5472-7 6

Konavko D., Moročko-Bičevska I., Bankina B. 2014 Pseudomonas syringae as important pathogen of fruit trees with emphasis on plum and cherry. Research for Rural Development, 1: 19-25.

Matveeva E. V., Ignatov A. N., Bobrova V. K., Milyutina I. A., Troitsky A. V., Polityko V. A., Schaad N. W. 2008. Genetic diversity among pseudomonad strains associated with cereal diseases in Russian Federation. Fatmi M. et al. (eds). Pseudomonas syringae Pathovars and Related Pathogens - Identification. Fnidemiology and Genomics. Snringer, p. 337-345. https://doi.org/10.1007/978-1-4020-6901-7 35

Morris C. E., Monteil C. L., Berge U. 2013. 'The life history of Pseudomonas syringae: linking agriculture to earth system nrocesses. Annulal Review of Phytonathology. 51: 85-104. https://doi.org/10.1146/annurev-phyto-082712-102402

Pasichnyk L. A., Butsenko L. M. 2018. Serological features of bacteria Pseudomonas syringae agroecosystems of cereal. Mikrohiolngichnyi 7hurnal, 80 (4): 41-54 (in Ukrainian). https://doi.org/10.15407/microbiolj80.04.041
Patyka V. P. 2016. Phytopathogenic bacteria in contemporary agriculture. Mikrohiologichnyi 7hurnal, 78 (6): 71-83. https://doi.org/10.15407/microbiolj78.06.071

Schaad N. W., Jones J. B., Chun W. (eds). 2001. Laboratory Guide for the Identification of Plant Pathogenic Bacteria ( ${ }^{\text {rd }}$ ed.) American Phytonatholngical Society, $373 \mathrm{p}$. https://doi.org/10.1046/j.1365-3059.2001.00635.x

Sundin G. W., Castiblanco L. F., Yuan X., Zeng Q., Yang C.-H. 2016. Bacterial disease management: challenges, experience, innovation and future prospects. Challenges in Bacterial Molecular Plant Patholngy Molecular Plant Pathology, 17 (9): 1506-1518. https://doi.org/10.1111/mpp.12436

Suszanowicz D., Patyka N. V., Patyka V. et al. 2019. Express diagnostics of phytopathogenic bacteria and phytoplasmas in agrophytocenosis: monograph. Phytopathogenic Bacteria in Contemporary Agriculture, $78 \mathrm{p}$.

Toben H., Mavridis A., Rudolph K. W. E. 1989. Basal glume rot (Pseudomonas syringae pv. atrofaciens) on wheat and barley in FRG and resistance screening of wheat. Bulletin OFPP/EPPO Bulletin. 19 (1): 119-125. https://doi.org/10.1111/j.1365-2338.1989.tb00137.x

Tripathi D. 2017. Bacterial pathogens in plants. Journal of Racterinloy and Mycoloov $4(?) \cdot 38-39$ https://doi.org/10.15406/jbmoa.2017.04.00083

Valencia-Botin A. J., Cisneros-López M. E. 2012. A review of the studies and interactions of Pseudomonas syringae pathovars on wheat International Inurnal of Agronomy, 2012: 692350. https://doi.org/10.1155/2012/692350

Vasinauskiene M. 1997. Occurrence and control of a Pseudomonas syringae pathovar causing bacterial lupine blotch. Rudolph K. et al. (eds). Pseudomonas syringae Pathovars and Related Pathogens. Developments in Plant Pathology. Snringer, vol. 9, n. 623-628 https://doi.org/10.1007/978-94-011-5472-7 113

Vasinauskienè M., Baranauskaitè L., Burokienè D. 2008. Search for Pseudomonas syringae on stone fruits in Lithuania. Annual Meeting of COST Action 873 STF meeting within WG1 Determination of the Incidence of the Different Pathovars of Pseudomonas syrinore in Stone Fruits Skierniewice, Poland, $11 \mathrm{n}$. httns://www.vumnu.com/ en/document $/ \mathrm{read} / 46665862 / \mathrm{search}$-for-pseudomonassyringae-on-stone-fruits-in-cost- 873

Xin X.-F., Kvitko B., He S. 2018. Pseudomonas syringae: what it takes to he a nathogen. Nature Reviews Microhinlogy, 16: 316-328. https://doi.org/10.1038/nrmicro.2018.17

\title{
Pseudomonas syringae patogeninès bakterijos Lietuvoje auginamuose javuose
}

\author{
J. Kelpšienè $\dot{1}^{1}$ D. Šneideris ${ }^{2}$, D. Burokienè ${ }^{2}$, S. Suproniené \\ ${ }^{1}$ Lietuvos agrarinių ir miškų mokslų centras \\ ${ }^{2}$ Gamtos tyrimų centras
}

\section{Santrauka}

Šiltejant klimatui ir kintant meteorologinèms sąlygoms, plinta ir naujos augalų ligos. Beveik visose vidutinio ir subtropinio klimato zonose javų bakterines ligas sukelia Pseudomonas syringae patogenai. Lietuvoje auginamuose migliniuose javuose $P$. syringae iki šiol nebuvo tirti, nes lyginant su grybinèmis ligomis, nedare didelès žalos. Tačiau pastaruoju metu pasèliuose gana dažnai pastebima grybinèms ir fiziologinėms ligoms nebūdingų lapų bei varpažvynių pažeidimų. Tyrimo tikslas - nustatyti $P$. syringae paplitimą Lietuvoje auginamuose javuose.

Tirti javų pasèliai, ar juose nèra paplitęs šis augalų patogenas. Per trejus tyrimo metus (2013-2015) iš viso buvo surinkti 452 simptominiai žieminių kviečių, žieminių kvietrugių, vasarinių kviečių ir vasarinių miežių èminiai. Lapu dèmètligès ir bazalinès bakteriozės pažeidimai gerokai dažniau buvo aptikti vasariniu ir žieminiu kviečiu nei žieminių kvietrugių ir vasarinių miežių pasèliuose. Iš simptominių lapų ir grūdų buvo išskirta 113 P. syringae kamienų (51 iš lapų ir 62 iš grūdų), tačiau testuojant purškimo metodu augalams šeimininkams buvo patogeniški tik 13 iš jụ: 10 iš kviečiu, 2 iš kvietrugių ir 1 iš miežiu. Šie kamienai buvo išskirti iš grūdu (10 kamienų) ir lapų (3 kamienai), surinktu ịvairiuose šalies rajonose. Atlikus 16S rRNR genų sekos analizę, lapų injekcijos testą ir nustačius patogeninių kamienų kilmę darytina prielaida, kad Lietuvoje dominuojantis javų bakterinių ligų sukèlëjas yra $P$. syringae pv. atrofaciens, ypač kviečių bazinès bakteriozès.

Tyrimo duomenys patvirtina, kad Lietuvoje auginamuose migliniuose javuose plinta $P$. syringae sukeliamos ligos, i kurias reikia atkreipti dèmesị.

Reikšminiai žodžiai: kviečiai, patogeninès bakterijos, bazalinė bakteriozè, lapų dèmètligè. 